\title{
Influence of Environmental Factors and Individual Gold Jewelry Buying Decision Against in Banjarmasin
}

\author{
Dyah Sri Wulandari ${ }^{1}$, Humaidi $^{2}$, Yuliarti Rezeki ${ }^{3}$ \\ \{dyahsriwulandari@gmail.com ${ }^{1}$ humaidibinsis@gmail.com² ${ }^{2}$ yuli.rezeki303@gmail.com ${ }^{3}$ \} \\ Department of Management University of Sari Mulia, Banjarmasin Indonesia ${ }^{1,2,3}$
}

\begin{abstract}
Gold jewelry is the type of products that are most frequently encountered in everyday life, many things that make someone decide to buy gold jewelry, this study aims to analyze the factors that influence the purchase decisions of gold jewelry, in which environmental factors and individual in the hypothesized effect on gold jewelry purchasing decisions. The population is a buyer of gold jewelry in the city of Banjarmasin, 220 respondents drawn using purposive sampling technique. Collecting data using questionnaires, while data analysis using Multiple Regression Analysis with SPSS version 23. The test results prove partially Environmental Factors on Purchase Decision $(\mathrm{Y})$ by $92 \%$, Factor Individuals to Purchase Decision $(\mathrm{Y})$ of $58.2 \%$ and simultaneous Environmental Factors and Factors Individuals to Purchase Decision (Y) amounted to $87.6 \%$ while the remaining $12.4 \%$ influenced by other variables not examined.
\end{abstract}

Keywords: Environmental factors, individual factors, Purchase Decision

\section{Introduction}

Consumers decided to buy and consume the product not just because of the value of their original function, but also because of their social value. Purchasing decisions is the behavior performed by different individuals. The individual is a potential consumer to buy a particular product offered by the company or found in the market.

Personal characteristics influence the buying decision include age, life cycle, occupation, economic circumstances, personality and self-concept and the values and lifestyle of the buyer. Someone buying goods and services vary throughout his life. The tastes of people towards the needs of clothing, food and shelter related to age. Consumption is also shaped by life sirklus family, number of family members, age and gender of people in the household at the time [1]

One consumer behavior that occurred in the city of Banjarmasin is the presence of some people who chose gold as a profitable investment option, because in addition to the investment, gold jewelry can also be used as a supporting appearance accessories. Based on 
the initial survey conducted by the authors, in the city of Banjarmasin the phenomenon of society, especially in certain circles are fond of using excessive gold jewelry, it is the one that turns the question, what was their purpose in taking the decision to buy gold jewelry as accessories jewelry, as an investment or other factors that make a person buy jewelry, such as environmental factors and individual factors.

In any economic situation remains much gold jewelry consumer demand, despite high gold prices, not reduce consumer buying interest towards gold jewelery products in because gold is considered as a lifestyle and savings for the future. The trade sector in Banjarmasin increasingly advanced from year to year with the increasing complexity of community needs and the increasing demand due to the increasing number of population.

There is a wide range of previous studies about the behavior of kosumen to gold, some of which give results or empirical evidence is different. Generally in India jeweleryhas always been associated with wealth, power and social status as well as having religious significance, the research in the Salem District no significant relationship between sex, marital status, age, education and income on purchasing behavior Gold, In contrast to research [2]. Which states that the lifestyle and gender significantly influence the purchasing decisions of Gold [3]. This condition indicates that an indicator of consumer behavior is vast and complex, the gap opinion about the factors that influence buying behavior of gold jewelry that is the research gap in this study, resulting from the diversity of the results of previous studies and the phenomena that occur in the city of Banjarmasin, so to determine the behavioral effects Gold jewelry buying lifted the title, the authors of this study, "Influence of Environmental Factors and Individual Gold Jewelry Buying Decision Against in Banjarmasin"

\subsection{Formulation of the problem}

The formulation of the problem in This research is as follows:

1. Whether there is a partial effectEnvironmental Factors againstgold jewelry purchasing decisions in Banjarmasin?

2. Whether there is a partial effect Individual factors against gold jewelry purchasing decisions in Banjarmasin?

3. Whether there is influence simultasn Environmental factors and individual factors togold jewelry purchasing decisions in Banjarmasin?

\subsection{Literature review}

Culture as used in behavioral studies kosnsumen, referring to the values, ideas, artifacts and other symbols are meaningful to help people communicate, interpretation and evaluation as members of society. However, from a different perspective, all forms of marketing is the channel where the cultural meaning is transferred to consumer goods. Thus, marketing is a transmitter that simultaneously values shape the culture and shaped by culture [4]

Social class is a division within society composed of individuals who share their values, interests and behavior of the same. They are distinguished by differences in socioeconomic status are lined up from the low to the high. Social class status often result in forms of different consumer behavior. Some of the earliest contributions to stusi consumer behavior using social class differences as the main variable in explaining differences in consumer [4]

As consumers, we are often influenced by the behavior of those who are closely related to us. We may respond to the perceived pressure to conform to the norms and expectations given by others. We also appreciate the people around us to advise them on the choice of purchase. This can take the form of observations on what was done by others, with the result that they 
become a comparative reference group. Personal influence is an important subject in consumer research since this research into the field of serious study [4]

The situation is clear that the behavior changed when the situation changes. Sometimes these changes are erratic and unpredictable. On other occasions, including, those changes can be predicted by research and exploited in the strategy. The situation is now treated as a variable of the study [4].

Behavior, perhaps the most important difference between individuals is the difference in resources [4]. Everyone carries three resources into the decision-making situations are time, money and attention (receiving information and processing capability). Generally there are obvious limitations on the availability of each, so that requires some sort of careful allocation [4].

Consumer engagement at how the presence or absence affects the behavior of the decision process. Because, a steering factor that is so potentially, that engagement is best understood as the primary motivating influence [4].

Knowledge, learning outcomes can be defined simply as the information stored in memory. Broad array of consumer knowledge includes information, such as the availability and characteristics of products and services, where and when to buy, and how to use the product. Therefore, the stimulation of awareness is often an important marketing goals and needs [4].

Attitude as a comprehensive evaluation that allows people respond to favorable or unfavorable manner consistent basis with respect to a given object or alternative. Attitude is the most important variables used in the study of human behavior [4].

Personality, lifestyle and demographics three useful in defining the objective and subjective characteristics of the consumers in the target market share. The marketing strategy should focus on the personality matching consumers with the product personality. Perhaps the greatest result of the era of personality research is focused expansion to cover lifestyle, patterns that people used to live and spend time and money. Goals in the field of demography is to describe the share of consumers such as age, income, and education. The emphasis is always on trend inside and spending behavior. When accompanied by piskografik research, demographics can provide information about the nature and composition of the market. Indeed, demography is a source of livelihood of marketing research [4].

\section{Research Method}

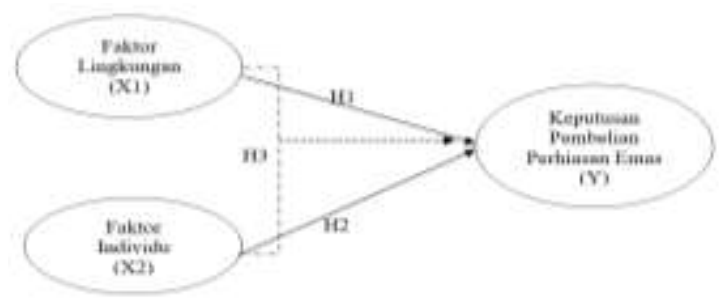

Fig 1. Model Research

based on The theoretical framework that has been described above, the hypothesis proposed in this study are: 
H.1 : There is the effect of Environmental Factors on gold jewelry purchasing decisions in Banjarmasin,

H.2 : There is the influence of individual factors on gold jewelry purchasing decisions in Banjarmasin,

H.3 : There is the influence of Environmental Factors and Individual Factors togold jewelry purchasing decisions in Banjarmasin.

Causality research is to describe the causal relationship between some of the situations described in a variable, and on that basis ditariklah a general conclusion [5]. Place the research done at consumers who have and buy gold jewelry in the city of Banjarmasin. , The sample in this study is that consumers have and buy gold jewelry in Banjarmasin with respondent characteristics were taken of men and women aged 18 years and older.

This study uses data collection techniques in the form of purposive sampling, ie sampling intentionally accordance with the requirements of samples with specific criteria and questionnaires, data collection techniques done by providing a set of questions or a written statement to the respondent to answer. The question that will be posed to consumers who have gold jewelery about what factors make them make a decision to buy gold jewelry. The author uses a Likert scale to measure the effect of variable environmental factors, pisikologis and individuals in this study, which is an attitude measurement technique most widely used in marketing research [6].

Engineering data was collected using a questionnaire which is a method of data collection by presenting a list of questions to the people who have and use gold jewelry in the city of Banjarmasin, the questionnaire is used as a tool in data collection has been designed in such a way by using the form that has been created previous

Tenik data analysis used in this study to analyze the data that was obtained was multiple linear regression in this study was to determine the research model.

a. $\mathrm{t}$ test

$\mathrm{T}$ test aims to determine the independent variables partially dependent. Tomengertahuiwhether there is a significant influence between variables each - each independent of the dependent variable, the significant value of $t$ compared with the degree of confidence. Decision-making is based on the results of SPSS 23.0 softwere then the decision is done by comparing the value sig./significance column sig. with significance level used (0.05). If sig./sifnificance> 0.05 then Ho is accepted whereas if sig./ sifnificance $<0.05$ then Ho is rejected

b. test $\mathrm{F}$

This test is used to test the effect of variable - the independent variables on the dependent variable simultaneously. $\mathrm{F}$ test was conducted to test all the independent variables on the dependent variable. The confidence level used is $95 \%$ with degrees of freedom $(\mathrm{df})=$ (k-1) (nk) or error rate $(\alpha)=5 \%$. Fhitung value $\geq$ Ftabel, the hypothesis Ho is rejected and Ha accepted hypothesis, the opposite of $\mathrm{F} \leq \mathrm{F}$ table, the hypothesis Ho is accepted and $\mathrm{Ha}$ is rejected

c. The coefficient of determination (R2)

The coefficient of determination (R2) essentially measures how far the model's ability to explain variations in the independent variable. Coefficient of determination is between zero and one. R2 small value means the ability of independent variables in explaining the variation of the dependent variable are very limited. A value close to the mean of independent variables provide almost all the information needed to predict the variation of the dependent variable [7]. This test was calculated using SPSS 23.0 softwere, 


\section{Result and Discussion}

Description of Respondents sample taken is a buyer and user of gold jewelry that reside in the city of Banjarmasin. As for the characteristics of the respondents can be seen in the tables on gender, age, education, occupation, and region of residence below:

Table 1. Characteristics of the sexes

\begin{tabular}{|c|c|c|}
\hline Gender & Frequency & percentage \\
\hline Man & 70 & $32 \%$ \\
\hline Woman & 150 & $68 \%$ \\
\hline Total & 220 & $100 \%$ \\
\hline
\end{tabular}

Sources: Primary data are processed, 2019

From the characteristics of the sexes can be explained that the purchase and use the gold jewelry are more women than men, men were 70 people $(32 \%)$ and women totaled 150 $(68 \%)$, there is a difference of 80 between the male respondents and female respondents. For ages the following characteristics

Table 2. characteristics of age

\begin{tabular}{|c|c|c|}
\hline Age & Frequency & percentage \\
\hline 20-30 years & 75 & $34 \%$ \\
\hline 31-40 years & 90 & $41 \%$ \\
\hline 41-50 years & $\mathbf{4 5}$ & $20 \%$ \\
\hline > 50 years & 10 & $5 \%$ \\
\hline Total & 220 & $100 \%$ \\
\hline
\end{tabular}

Sources: Primary data are processed, 2018

Age buyer once the most gold jewelry consumer in the age range of 31-40 years amounted to 90 respondents $(41 \%)$ it is very reasonable for the range of age is a productive worker who has worked several years so it's been quite able to buy gold jewelry, then the range age 20-30 years are the most in both the 75 respondents (34\%), and the third row and so is the age range of 41-50 years were 45 respondents (20\%), and lastly the age range of at least buyers and the gold jewelry are the age ranges of more than 50 years of 10 people $(5 \%)$. For education the following characteristics:

Table 3. Educational characteristics

\begin{tabular}{|c|c|c|}
\hline last education & Frequency & percentage \\
\hline SD & 5 & $3 \%$ \\
\hline SMP / equivalent & 35 & $16 \%$ \\
\hline SMA / SMK / equivalent & 80 & $36 \%$ \\
\hline Diploma & 25 & $11 \%$ \\
\hline Degree / Post graduate & 75 & $34 \%$ \\
\hline Total & 220 & $100 \%$ \\
\hline
\end{tabular}

Sources: Primary data are processed, 2019

Furthermore, when viewed from the educational characteristics are known buyers of gold jewelry the most is the educational background of SMA / SMK / equivalent as many as 80 people $(36 \%)$, followed by educational background Bachelor of as many as 75 people 
(34\%), followed by education background Diploma sabanyak 25 people (11\%), and educational backgrounds are a little buying and wearing gold jewelry is a junior high school education were $35(16 \%)$ and elementary education as much as 5 people (3\%). For job characteristics are as follows:

Table 4. Characteristics of the work

\begin{tabular}{|c|c|c|}
\hline Work & Frequency & percentage \\
\hline College student & 10 & $5 \%$ \\
\hline PNS & 60 & $27 \%$ \\
\hline Private employees & 70 & $32 \%$ \\
\hline entrepreneur & 80 & $36 \%$ \\
\hline Total & 220 & $100 \%$ \\
\hline
\end{tabular}

Sources: Primary data are processed, 2019

Employment characteristics of the buyers and users of gold jewelry Most are selfemployed with a number of 80 people $(36 \%)$, next is private employees with a total of 70 people $(32 \%)$, and then PNS of 60 people $(27 \%)$ and the last student of 10 people (5\%). Biggest buyers with work self-employed and private employees. Furthermore, to the characteristics of residential areas can be explained as follows:

Table 5. Residential areas

\begin{tabular}{|c|c|c|}
\hline Residential areas & Frequency & percentage \\
\hline District. Banjarmasin middle & 50 & $23 \%$ \\
\hline District. Banjarmasin west & 45 & $20 \%$ \\
\hline District. Banjarmasin north & 40 & $18 \%$ \\
\hline District. Banjarmasin east & 35 & $16 \%$ \\
\hline District. Banjarmasin south & 50 & $23 \%$ \\
\hline Total & 220 & $100 \%$ \\
\hline
\end{tabular}

Sources: Primary data are processed, 2019

Based on residential areas that respondents there have distribution of residential areas were almost evenly distributed throughout the sub-district of Banjarmasin, the composition of the region Banjarmasin middle of 50 people $(23 \%)$, the area of Banjarmasin south as many as 50 people $(23 \%)$, the area of Banjarmasin west as many as 45 people $(20 \%)$, Banjarmasin area north of 40 people $(18 \%)$ and Banjarmasin eastern region were $35(16 \%)$.

\section{Partial test ( $t$ test)}

$\mathrm{T}$ test aims to determine the variables Environmental Factors and Individual factors have an influence on gold jewelry purchasing decisions in Banjarmasin ie by comparing the value of $t$ arithmetic with $t$ table with a significance of $95 \%(\alpha=0.05)$.

1. Ho: if the $\mathrm{P}$ value $>0.05$ or $\mathrm{t}>\mathrm{t}$ table, then Ho is accepted.

2. Ho: if $P$ value $<0.05$ or $t<t$ table, then Ho is rejected. 
Tabel 6. Coefficientsa

\begin{tabular}{|c|c|c|c|c|c|c|}
\hline \multirow{2}{*}{\multicolumn{2}{|c|}{ Model }} & \multicolumn{2}{|c|}{ Coefficients unstandardized } & $\begin{array}{l}\text { standardized } \\
\text { Coefficients }\end{array}$ & \multirow[t]{2}{*}{$\mathrm{t}$} & \multirow[t]{2}{*}{ Sig. } \\
\hline & & B & Std. Error & beta & & \\
\hline \multirow[t]{3}{*}{1} & (Constant) & 5,561 & 2,138 & & 2,600 & .011 \\
\hline & Environmental factor & .436 & .019 & .920 & 23341 & .000 \\
\hline & Individual factors & .183 & .040 & .582 & 2,090 & .040 \\
\hline
\end{tabular}

a. Dependent Variable: Purchase Decision

Source: data processing, SPSS 23:00, 2019

Based on the calculation, a significant value $t$ for the independent variables, namely:

a. Environmental Factors Variable t value amounted to 23 341, while t table of 1.66298.

With sifnifikan 0,000. Because t count $>\mathrm{t}$ table $(23341>1.66298)$ or sig $\mathrm{t}<5 \%(0.000$

$<0.05)$, the Ha Ho accepted and rejected, meaning that a significant difference in partial Environmental Factors ongold jewelry purchasing decisions in Banjarmasin,

b. Individual Factors Variable $t$ value of 2.090 while $t$ table amounted to 1.66298 . With sifnifikan amounted to 0,040 . Because $t$ count $>t$ table $(2.090>1.66298)$ or sig $t<5 \%$ $(0.040<0.05)$, the Ha Ho accepted and rejected, meaning that a significant difference in partial Individual Factors togold jewelry purchasing decisions in Banjarmasin

From the above test results it can be concluded that there is significant influence partially variable Environmental Factors against gold jewelry purchasing decisions in BanjarmasinAnd a significant difference in partial Individual Factors to gold jewelry purchasing decisions in Banjarmasin, The dominant influence and the regression coefficient is greatest variable Environmental factors that can be seen from the regression coefficient of 0436 and nesar influence $92 \%$

\section{Simultaneous Test (Test F)}

This test is used to determine all of the independent variables and the Environmental Factors Individual Factors in together (simultaneously) the effect on the dependent variable gold jewelry purchasing decisions in Banjarmasin, The test is performed by $\mathrm{F}$ test, with a significance level of $95 \%(\alpha=0.05)$. F test results can be seen in the table below 7 :

Table 7. regression test results semultan (f)

\begin{tabular}{|l|l|r|r|r|r|r|}
\hline \multicolumn{2}{|c|}{ Model } & Sum of Squares & df & mean Square & F & \multirow{2}{*}{ Sig. } \\
\hline \multirow{2}{*}{1} & Regression & 1489.060 & 2 & 744530 & 288364 & $.000 \mathrm{~b}$ \\
\cline { 2 - 7 } & residual & 211716 & 82 & 2,582 & & \\
\cline { 2 - 7 } & Total & 1700.776 & 84 & & & \\
\hline
\end{tabular}

Dependent Variable: Purchase Decision

Predictors: (Constant), Indiividu factors, environmental factors

Source: data processing, SPSS 23:00, 2019 
Based on the calculation, a significant value $\mathrm{F}(0,000)<$ significant $\alpha(0.05)$, namely $(0.000<0.05)$ or by comparing $F$ arithmetic with $F$ table with a value of $F$ table 82 . Where the results of calculations obtained F count $>\mathrm{F}$ table $(288364>3.11)$. Based on these calculations then the decision is Ho rejected and Ha accepted which means that statistically can be proved that all the independent variables consisting Environmental Factors and Individual factors together (simultaneously) influencegold jewelry purchasing decisions in Banjarmasin,

The coefficient of determination (R2)

The coefficient of determination (R2) essentially measures how much a component model in explaining variations in the independent variable. Coefficient of determination is between zero and one (Ghozali, 2006: 83). Terminated coefficient values can be seen in the table below 7 . 
Table 7. Coefficient of determination

\begin{tabular}{|c|c|c|c|c|c|c|c|c|c|c|}
\hline \multicolumn{11}{|c|}{ Model Summary b } \\
\hline \multirow[b]{2}{*}{ Model } & \multirow[b]{2}{*}{$\mathrm{R}$} & \multirow[b]{2}{*}{$\begin{array}{c}\mathrm{R} \\
\text { Square }\end{array}$} & \multirow[b]{2}{*}{$\begin{array}{l}\text { Adjusted } \\
\text { R Square }\end{array}$} & \multirow{2}{*}{$\begin{array}{l}\text { Std.Error } \\
\text { of the } \\
\text { Estimate }\end{array}$} & \multicolumn{5}{|c|}{ Change Statistics } & \multirow[b]{2}{*}{$\begin{array}{l}\text { Durbin- } \\
\text { Watson }\end{array}$} \\
\hline & & & & & $\begin{array}{c}\mathrm{R} \\
\text { Square Change }\end{array}$ & Change & DF1 & DF2 & Change & \\
\hline 1 & $\begin{array}{r}.936 \\
\mathrm{a}\end{array}$ & .876 & .872 & 1,607 & .876 & 288364 & 2 & 82 & .000 & 1,876 \\
\hline
\end{tabular}


Based on calculations using SPSS in Table 7 knowable terminated coefficient ( $R$ square) obtained for 0876 . This means that $87.6 \%$ gold jewelry purchasing decisions in Banjarmasin can be explained by the variable Environmental Factors and Individual Factor, while the remaining $12.4 \%$ gold jewelry purchasing decisions in Banjarmasin influenced by other variables not examined in this study

\section{Conclusions}

Based on the research that has been described previously, it can be concluded as follows:

1. Environmental factors such as cultural and personal influences significantly influence the purchasing decisions of gold jewelry in the city of Banjarmasin

2. Individual factors such as consumer resources, motivation, lifestyle, information, learning and behavior significantly influence the purchasing decisions of gold jewelry in the city of Banjarmasin

3. Environmental factors and individual factors significantly influence the purchasing decisions of gold jewelry in the city Banjarmasi

\section{References}

[1] Kotler, Philip, Keller, K., L.: "Manajemen Pemasaran”, Jilid 1 dan 2, edisi kedua belas, Indeks, Jakarta (2009)

[2] Depaa dan Natarajan.: A Study of Customers Attitude And Behaviour On Jewellery Purchase In Salem District. India International Journal of Research In Commerce and Management Vol.4 February 2013 (2013)

[3] Sujatha, Kumaresan.: Influence of Lifestyle Perception on Gold Purchase Decisions. Global Research Analysis Vol.2 Issue.7 July 2013 (2013)

[4] Engel, J. F., Balckwell, R. D., Miniard, P.W.: Perilaku Konsumen, Jilid 1 dan 2, edisi keenam, Binarupa Aksara, Jakarta (1994)

[5] Ferdinand, A.: Metode Penelitian Manajemen, Edisi kedua, Badan Penerbit Universitas Diponegoro, Semarang (2006)

[6] J. Supranto.: Statistik Teori dan Aplikasi, Cetakan Kedua, Jakarta: Penerbit Erlangga (2001)

[7] Ghozali Imam.: Statistik Non-parametrik, Universitas Diponegoro, Semarang (2006) 